\title{
On the limits of Antarctic and marine climate records synchronization: Lag estimates during marine isotopic stages $5 \mathrm{~d}$ and $5 \mathrm{c}$
}

\author{
A. Landais \\ Laboratoire des Sciences du Climat et de 1'Environnement, Institut Pierre-Simon Laplace, Gif sur Yvette, France \\ Institute of Earth Sciences, Givat Ram, Hebrew University, Jerusalem, Israel \\ C. Waelbroeck and V. Masson-Delmotte \\ Laboratoire des Sciences du Climat et de l'Environnement, Institut Pierre-Simon Laplace, Gif sur Yvette, France \\ Received 19 April 2005; revised 11 October 2005; accepted 3 November 2005; published 20 January 2006.
}

[1] North Atlantic sediment records (MD95-2042), Greenland (Greenland Ice Core Project (GRIP)) and Antarctica (Byrd and Vostok) ice core climate records have been synchronized over marine isotopic stage 3 (MIS 3) (64 to 24 kyr B.P.) (Shackleton et al., 2000). The resulting common timescale suggested that MD95-2042 $\delta^{18} \mathrm{O}_{\text {benthic }}$ fluctuations were synchronous with temperature changes in Antarctica $\left(\delta \mathrm{D}_{\text {ice }}\right.$ or $\delta^{18} \mathrm{O}_{\text {ice }}$ records). In order to assess the persistency of this result we have used here the recent Greenland NorthGRIP ice core covering the last glacial inception. We transfer the Antarctic Vostok GT4 timescale to NorthGRIP $\delta^{18} \mathrm{O}_{\text {ice }}$ and MD95-2042 $\delta^{18} \mathrm{O}_{\text {planktonic }}$ records and precisely quantify all the relative timing uncertainties. During the rapid warming of Dansgaard-Oeschger 24, MD95-2042 $\delta^{18} \mathrm{O}_{\text {benthic }}$ decrease is in phase with $\delta^{18} \mathrm{O}_{\text {planktonic }}$ decrease and therefore with NorthGRIP temperature increase, but it takes place $1700 \pm$ 1100 years after the Antarctic warming. Thus the present study reveals that the results obtained previously for MIS 3 cannot be generalized and demonstrates the need to improve common chronologies for marine and polar archives.

Citation: Landais, A., C. Waelbroeck, and V. Masson-Delmotte (2006), On the limits of Antarctic and marine climate records synchronization: Lag estimates during marine isotopic stages 5d and 5c, Paleoceanography, 21, PA1001,

doi:10.1029/2005PA001171.

\section{Introduction}

[2] High-resolution climate records extracted from marine sediments and polar ice cores have provided crucial information on the mechanisms of past climate change [e.g., Petit et al., 1999; Alley et al., 2003]. In particular, the occurrence of abrupt climatic changes during the last glacial period (Dansgaard-Oeschger events, hereafter DO) has been discovered almost simultaneously in Greenland ice cores and in North Atlantic marine cores in the 1980s and 1990s [Dansgaard et al., 1984, 1993; Grootes et al., 1993; Labeyrie and Duplessy, 1985; Bond et al., 1993; McManus et al., 1994; Cortijo et al., 1995; Shackleton et al., 2000; de Abreu et al., 2003; Labeyrie et al., 2004; Martrat et al., 2004; North Greenland Ice Core members, 2004].

[3] Marine records have revealed a strong link between northern Atlantic temperature changes and variations of the thermohaline circulation (THC) intensity [Broecker et al., 1985; McManus et al., 2004]. Combining information from different North Atlantic cores, it has been suggested that rapid temperature changes and $\mathrm{THC}$ variations during marine isotopic stage 3 (MIS 3) are linked to icebergs

Copyright 2006 by the American Geophysical Union. 0883-8305/06/2005PA001171 discharges from the Laurentide or the Fennoscandian ice sheets [Broecker, 1994; Bond et al., 1997; Elliot et al., 2002], together with possible rapid variations of sea level [Chappell, 2002; Siddall et al., 2003].

[4] Antarctic ice cores exhibit a Southern Hemisphere counterpart of most northern Atlantic rapid events, with, however, different shapes and amplitudes [Bender et al., 1994]. The bipolar synchronization of ice cores is possible owing to the global signals of atmospheric composition changes [Bender et al., 1994, 1999; Blunier et al., 1998; Blunier and Brook, 2001; Caillon et al., 2003a] and reveals that temperatures slowly rise in the south (with amplitudes of $2^{\circ} \mathrm{C}$ to $5^{\circ} \mathrm{C}$ [Jouzel et al., 2003]), approximately 2 kyrs before temperatures abruptly rise in the north (by $8^{\circ} \mathrm{C}$ to $16^{\circ} \mathrm{C}$ in Greenland [Severinghaus and Brook, 1999; Lang et al., 1999; Landais et al., 2004a; C. Huber et al., Isotope calibrated Greenland temperature record over marine isotope stage 3 and its relation to $\mathrm{CH}_{4}$, submitted to Earth and Planetary Science Letters, 2005]) in agreement with a seesaw mechanism driven by THC variations [Stocker, 1998; Stocker and Johnsen, 2003; Knutti et al., 2004].

[5] Variations of sea level exhibiting the same temporal pattern as Antarctic ice isotopic records have been suggested from coral terraces [Yokoyama et al., 2001; Chappell, 
2002; Potter et al., 2004] and oxygen isotopic measurements of foraminifera calcite [Shackleton et al., 2000; Siddall et al., 2003]. While sea level reconstructions based on coral terraces cannot capture rapid changes continuously, those obtained from benthic foraminifera oxygen isotopes $\left(\delta^{18} \mathrm{O}_{\text {benthic }}\right)$ are hindered by possible temperature and water mixing effects [Chappell and Shackleton, 1986; Rohling and Bigg, 1998; Waelbroeck et al., 2002; Skinner et al., 2003]. Despite these difficulties, it has been suggested that a large part of the $\delta^{18} \mathrm{O}_{\text {benthic }}$ rapid variability reflects rapid ice volume variations [Shackleton et al., 2000; Siddall et al., 2004].

[6] The mechanisms linking changes in ice sheet dynamics, ocean circulation and climate are still poorly understood. In order to progress we need to determine the precise sequence of events between marine and ice core records and hence a common time frame. For this purpose, it is commonly assumed that North Atlantic SST changes occur in phase with changes in Greenland $\delta^{18} \mathrm{O}_{\text {ice, }}$, a proxy for air surface temperature above the ice sheet. Many authors assumed that North Atlantic $\delta^{18} \mathrm{O}_{\text {planktonic }}$ was a proxy for SST and therefore correlated high-resolution North Atlantic $\delta^{18} \mathrm{O}_{\text {planktonic }}$ records with Greenland $\delta^{18} \mathrm{O}_{\text {ice }}$ records [Bond et al., 1993; McManus et al., 1994]. Shackleton et al. [2000] invoked the rapid migration of the polar front to derive a chronology for Iberian margin MD95-2042 records by correlating MD95-2042 $\delta^{18} \mathrm{O}_{\text {planktonic }}$ with Greenland GRIP $\delta^{18} \mathrm{O}_{\text {ice }}$ between $64 \mathrm{kyr}$ B.P. and $24 \mathrm{kyr}$ B.P. (roughly corresponding to MIS 3). Taking advantage of Blunier et al. [1998] and Bender et al. [1994] gas correlations of Greenland and Antarctic ice cores over the last glacial period, Shackleton et al. [2000] then directly compared their North Atlantic $\delta^{18} \mathrm{O}_{\text {benthic }}$ record to the Vostok temperature record $\left(\delta D_{\text {ice }}\right)$. They concluded that both signals were synchronous and further stated that global ice volume varied in phase with Antarctic temperature. Such a synchronicity between MD95-2042 $\delta^{18} \mathrm{O}_{\text {benthic }}$ and $\delta \mathrm{D}_{\text {ice }}$ in Antarctica, if persistent through time, would constitute an important stratigraphic tool to derive a common chronological framework for marine and polar archives.

[7] It has already been shown, over the terminations, that the $\delta^{18} \mathrm{O}_{\text {benthic }}$ decrease is delayed by several thousand years with respect to the Antarctic $\delta \mathrm{D}_{\text {ice }}$ increase [Shackleton, 2000], and that $\delta^{18} \mathrm{O}_{\text {benthic }}$ records from different oceans [Skinner and Shackleton, 2005] and from different water depths (L. Labeyrie et al., Changes in deep water hydrology during the last deglaciation, submitted to Comptes Rendus Geosciences, 2005) are not synchronous. Here we explore the relationship between $\delta^{18} \mathrm{O}_{\text {benthic }}$ and Vostok $\delta \mathrm{D}_{\text {ice }}$ during the onset of the last glacial period, i.e., over the DO 25 to 23. This study is made possible because of the (1) new NorthGRIP Greenland deep ice core, which provides for the first time a continuous and high-resolution record of the glacial inception in Greenland [North Greenland Ice Core members, 2004], and (2) construction of a common temporal framework between Vostok and NorthGRIP ice cores showing the sequence of bipolar climate changes taking place during the last glacial inception [Landais et al., 2005a], here extended to MD95-2042 core between 112 and 101 kyr B.P., i.e., covering the transition between marine isotopic stages $5 \mathrm{~d}$ and $5 \mathrm{c}$.

\section{Common Timescale for NorthGRIP $\delta^{18} \mathrm{O}_{\text {ice }}$, Vostok $\delta D_{\text {icee }}$ and MD95-2042 $\delta^{18} O_{\text {planktonic }}$ and MD95-2042 $\delta^{18} \mathrm{O}_{\text {benthic }}$}

2.1. Data

[8] Core MD95-2042 was collected during the 1995 International Marine Global Change Study (IMAGES). $\delta^{18} \mathrm{O}_{\text {planktonic }}$ and $\delta^{18} \mathrm{O}_{\text {benthic }}$ were measured with an average temporal resolution of $\sim 350$ years during stages $5 \mathrm{~d}$ to $5 \mathrm{c}$ [Shackleton et al., 2000, 2002]. Here we use the Vostok $\delta \mathrm{D}_{\text {ice }}$ record [Petit et al., 1999] as a proxy for Antarctic temperature [Caillon et al., 2001; Jouzel et al., 2003]. The temporal resolution of the $\delta \mathrm{D}_{\text {ice }}$ profile for the last glacial inception is $\sim 80$ years resulting from measurements conducted on $1 \mathrm{~m}$ samples. The NorthGRIP $\delta^{18} \mathrm{O}_{\text {ice }}$ profile [North Greenland Ice Core members, 2004] is available at a $50 \mathrm{~cm}$ resolution which corresponds to a $\sim 50$ year resolution during the glacial inception.

[9] In order to construct a common chronological framework between these two ice cores the air trapped in Vostok and NorthGRIP ice core was analyzed: (1) methane measurements on Vostok ice [Petit et al., 1999; Delmotte et al., 2004] including detailed measurements on the transition from stage $5 \mathrm{~d}$ to stage $5 \mathrm{c}$ with a resolution of $\sim 80$ years [Caillon et al. 2003a] and a few methane measurements on the bottom part of the NorthGRIP ice core with a resolution of $\sim 600$ years [North Greenland Ice Core members, 2004]; (2) isotopic composition of the atmospheric oxygen $\left(\delta^{18} \mathrm{O}_{\mathrm{atm}}\right.$, a marker of global ice volume and biospheric productivity) in Vostok with a time resolution of 1000-2000 years [Petit et al., 1999] and in NorthGRIP with a mean time resolution of $\sim 50$ years [Landais et al., 2005a].

[10] To compensate for the low resolution of the NorthGRIP methane record at the onset of DO 24 (see section 2.2), we use $\delta^{15} \mathrm{~N}$ measurements performed on the NorthGRIP ice core with a mean resolution of $\sim 50$ years (same samples as for $\left.\delta^{18} \mathrm{O}_{\mathrm{atm}}\right)$. The $\delta^{15} \mathrm{~N}$ profile records changes in pore close-off depth (gravitational fractionation) and rapid surface temperature variations (thermal fractionation) [Severinghaus et al., 1998].

\subsection{NorthGRIP on Vostok GT4 Timescale}

[11] Because of their high residence time $(\sim 10$ years for $\mathrm{CH}_{4}$ and $\sim 1500$ years for $\left.\delta^{18} \mathrm{O}_{\mathrm{atm}}\right)$ compared to the interhemispheric mixing time $(\sim 1$ year), past methane and $\delta^{18} \mathrm{O}_{\text {atm }}$ variations recorded in air bubbles from ice cores from Greenland and Antarctica can be considered as synchronous and are therefore extensively used as correlation tools between different ice records [Bender et al., 1994, 1999; Blunier et al., 1998; Blunier and Brook, 2001; Landais et al., 2003]. We used here the Vostok and NorthGRIP methane and $\delta^{18} \mathrm{O}_{\text {atm }}$ measurements described in section 2.1 to transfer the Vostok GT4 time timescale [Petit et al., 1999] to the NorthGRIP ice core over the glacial inception according to the procedure detailed below [Landais et al., 2005a]. 


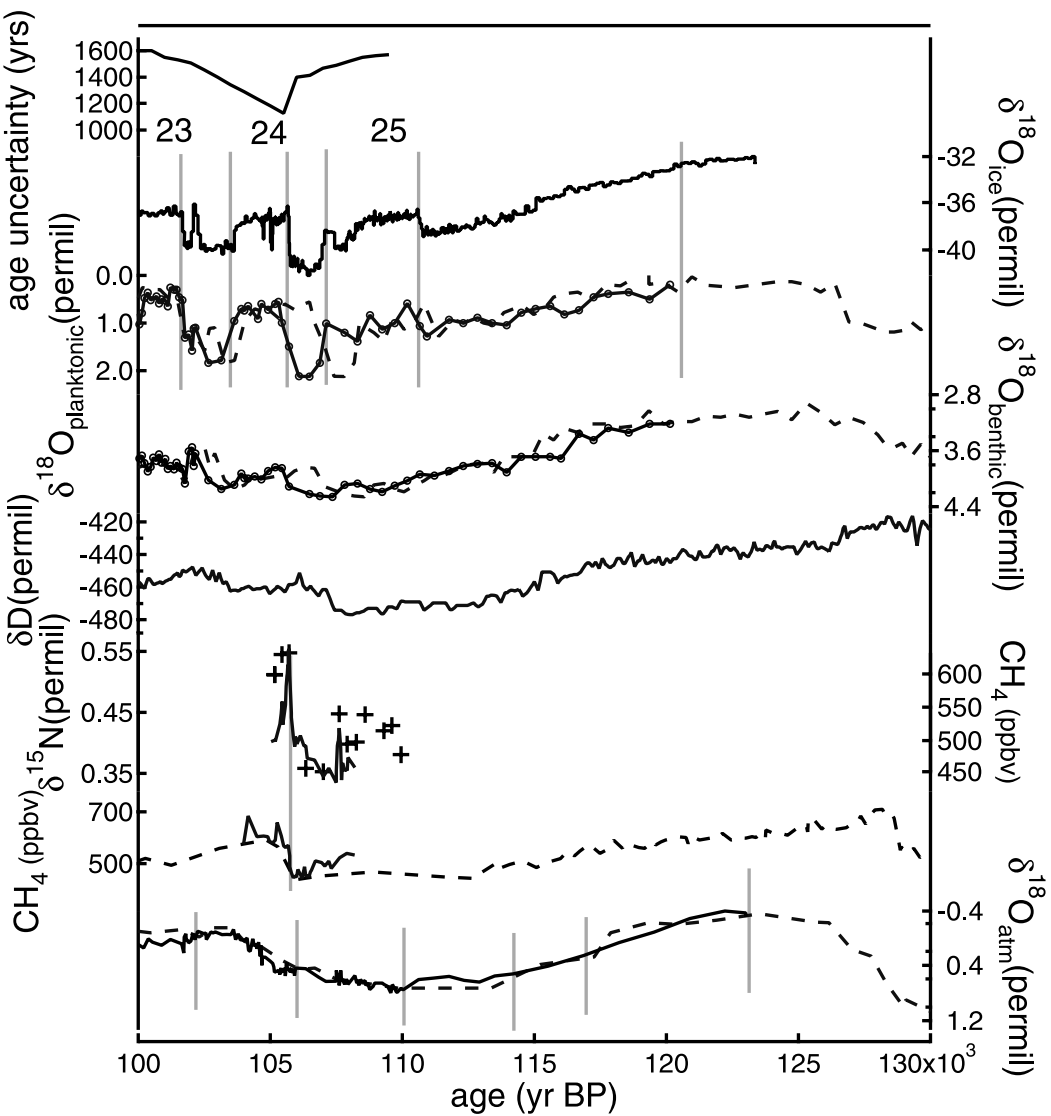

Figure 1. (top to bottom) Total age uncertainty on the correlation Vostok $\delta D_{\text {ice }}-M D 95-2042 \delta^{18} \mathrm{O}_{\text {benthic }}$. The tie point between NorthGRIP $\delta^{18} \mathrm{O}_{\text {ice }}$ and MD95-2042 over the 5e plateau is too uncertain to calculate the error bar before the onset of DO 25. NorthGRIP $\delta^{18} \mathrm{O}_{\text {ice }}$ [North Greenland Ice Core members, 2004] on the GT4 timescale. MD95-2042 $\delta^{18} \mathrm{O}_{\text {planktonic }}$ on its own timescale (dashed line [Shackleton et al., 2003]) and on the GT4 timescale (solid line with data points). MD95-2042 $\delta^{18} \mathrm{O}_{\text {benthic }}$ on its own timescale (dashed line [Shackleton et al., 2003]) and on the GT4 timescale (solid line with data points). Vostok $\delta \mathrm{D}_{\text {ice }}$ on the GT4 timescale [Petit et al., 1999]. NorthGRIP $\mathrm{CH}_{4}$ (crosses) [North Greenland Ice Core members, 2004] and NorthGRIP $\delta^{15} \mathrm{~N}$ over DO 24 (solid line) [Landais et al., 2005a]. Vostok $\mathrm{CH}_{4}$ profile on the gas GT4 timescale (dashed [Petit et al., 1999] and solid [Caillon et al., 2003a]). Vostok (dashed line [Petit et al., 1999]) and NorthGRIP (solid line [Landais et al., 2005a]) $\delta^{18} \mathrm{O}_{\mathrm{atm}}$ on the GT4 timescale. The grey vertical lines show the tie points chosen to correlate on the GT4 timescale (1) the $\delta^{18} \mathrm{O}_{\text {atm }}$ profiles in NorthGRIP and in Vostok, (2) the NorthGRIP $\mathrm{CH}_{4}$ and $\delta^{15} \mathrm{~N}$ with the Vostok $\mathrm{CH}_{4}$, and (3) the NorthGRIP $\delta^{18} \mathrm{O}_{\text {ice }}$ with the MD95-2042 $\delta^{18} \mathrm{O}_{\text {planktonic. }}$

[12] We first selected 6 tie points at midslope, minimum and maximum values of the $\delta^{18} \mathrm{O}_{\mathrm{atm}}$ profiles (Figure 1). The smooth $\delta^{18} \mathrm{O}_{\text {atm }}$ profiles do not provide temporal constraints better than $\sim 1000$ years (Table 1 ). To improve the NorthGRIP/Vostok gas correlation, we add a tie point based on the identification of the abrupt DO 24 methane increase in NorthGRIP [North Greenland Ice Core members, 2004] and in Vostok [Caillon et al., 2003a] (Figure 1 and Table 1). The methane measurements resolution is low in NorthGRIP ( $\sim 600$ years). However, it has been shown that rapid $\delta^{15} \mathrm{~N}$ and $\mathrm{CH}_{4}$ increases at the beginning of DO events are synchronous ( \pm 50 years) and reflect rapid temperature increases in Greenland [Severinghaus et al., 1998; Flückiger et al., 2004, Landais et al., 2004b; Chappellaz et al., 1993]. Such a property enables us to obtain a minimal uncertainty for this tie point $( \pm 100$ years with respect to 350 years using $\mathrm{CH}_{4}$ correlation only).

[13] Summarizing, the uncertainties on gas correlations between NorthGRIP and Vostok vary between $\sim 100$ and $\sim 1500$ years during the glacial inception. In order to transfer this common timescale from the gas records to the ice records, one has to take into account the uncertainty on the age difference between the ice and the gas $(\Delta$ age $)$. The $\Delta$ age results from the fact that air is entrapped at the bottom of the firn: at each depth level, the air is younger than the surrounding ice. The $\Delta$ age is usually computed from estimates of surface temperature, accumulation rate using an empirical or mechanistic model that expresses close-off depth and $\Delta$ age as a function of these variables [Barnola et al., 1991; Schwander et al., 1997; Arnaud et al., 
Table 1. Gas Tie Points Used to Correlate NorthGRIP and Vostok Records by Minimizing the Area Between the NorthGRIP and Vostok $\delta^{18} \mathrm{O}_{\mathrm{atm}}$ Records and Associated Age Uncertainties ${ }^{\mathrm{a}}$

\begin{tabular}{cccc}
\hline Depth NorthGRIP, $\mathrm{m}$ & Age Vostok, years B.P. & Uncertainty, years & Gas Tracer \\
\hline 2897.4 & 102,070 & 1,200 & $\delta^{18} \mathrm{O}_{\mathrm{atm}}$ \\
2944.7 & 105,740 & 100 & $\mathrm{CH}_{4}$ \\
2946.4 & 105,940 & 1,000 & $\delta^{18} \mathrm{O}_{\mathrm{atm}}$ \\
3000 & 110,000 & 1,000 & $\delta^{18} \mathrm{O}_{\mathrm{atm}}$ \\
3038 & 114,000 & 1,200 & $\delta^{18} \mathrm{O}_{\mathrm{atm}}$ \\
3049.8 & 116,870 & 1,200 & $\delta^{18} \mathrm{O}_{\mathrm{atm}}$ \\
3075 & 123,000 & 1,500 & $\delta^{18} \mathrm{O}_{\mathrm{atm}}$ \\
\hline
\end{tabular}

${ }^{a}$ Uncertainty associated with the $\delta^{18} \mathrm{O}_{\text {atm }}$ Vostok GT4 tie points is mainly due to the smoothed shape and low resolution of the Vostok $\delta^{18} \mathrm{O}_{\mathrm{atm}}$ record making it difficult to clearly define midslopes, maxima and minima of the $\delta^{18} \mathrm{O}_{\text {atm }}$ profile. The $\mathrm{CH}_{4}$ tie point $(2944.7 \mathrm{~m})$ is better defined: We associated the age at the midslope of the Vostok $\mathrm{CH}_{4}$ record [Caillon et al., 2003a] with the depth of the rapid $\mathrm{CH}_{4}$ and $\delta^{15} \mathrm{~N}$ (i.e., temperature) increase recorded in NorthGRIP gas.

2000; Goujon et al., 2003]. It becomes particularly large when temperature and accumulation rate are extremely low (up to 7000 years during the glacial period at Vostok). Although sensitivity studies conducted with different firn densification models lead to a $\sim 10 \%$ uncertainty for the simulated $\Delta$ age, the ability of such models to predict firn depth changes at Antarctic sites characterized by low present-day temperature and accumulation rates $\left(<-50^{\circ} \mathrm{C}\right.$ and $<3 \mathrm{~cm}$ ice equivalent. $\mathrm{yr}^{-1}$ ) is questioned [Caillon et al., 2003b; Goujon et al., 2003; Landais et al., 2005b].

[14] The uncertainty of $10 \%$ for the model estimate of the $\Delta$ age in NorthGRIP (i.e., less than 100 years) is realistic and verified by model-data comparisons [Landais et al., 2005a]. Figure 1 shows that the onset of DO 24 recorded in the $\delta^{18} \mathrm{O}_{\text {ice }}$ (rapid increase) and in the $\delta^{15} \mathrm{~N}$ (positive peak) records are indeed synchronous.

[15] In Vostok, a property linked to the firn close-off depth is registered in the $\delta^{15} \mathrm{~N}$ via gravitational fractionation: the $\delta^{15} \mathrm{~N}$ is proportional to the thickness of past firn diffusive zone. Assuming, like in most firn densification models, that there is no convective zone preventing gravitational enrichment at the top of the firn, the $\delta^{15} \mathrm{~N}$ should be directly related to the past pore close-off depth. The air isotopic measurements $\left(\delta^{15} \mathrm{~N}\right)$ conducted on the Vostok ice core [Sowers et al., 1992; Caillon et al., 2001; Caillon et al., 2003b] show values up to $30 \%$ less than the model estimates during full glacial periods and $\sim 15 \%$ less for the $5 \mathrm{~d} / 5 \mathrm{c}$ transition. We therefore use this disagreement between model and measurements to estimate the largest error bar on our $\Delta$ age determination in Vostok: $\delta^{15} \mathrm{~N}$ inferred changes in firn close-off depth are translated in a $\Delta$ age using the ice core age model [Petit et al., 1999; Parrenin et al., 2004]. Including the uncertainty linked to the age model, the resulting error on the determination of Antarctic $\Delta$ age is lower or equal to $20 \%$ (i.e., $\sim 1000$ years over the $5 \mathrm{~d} / 5 \mathrm{c}$ transition).

[16] Note that a $20 \%$ error bar on the Vostok $\Delta$ age is probably an overestimate for at least two reasons. First, we have neglected the possible existence of a convective zone but recent field measurements on very low temperature and accumulation rate Antarctic sites (analog to Vostok during the last glacial period [Severinghaus et al., 2004]) have revealed an upper convective zone of more than $20 \mathrm{~m}$. A larger convective zone would reconcile large close-off depths simulated by firn models and low $\delta^{15} \mathrm{~N}$ values which indicate a smaller diffusive zone. Second, direct estimates of the Vostok $\Delta$ age performed by Caillon et al. [2001, 2003b] suggest that $\Delta$ age estimates remain at $10 \%$ on the $5 \mathrm{~d} / 5 \mathrm{c}$ transition and over Termination III (240 kyr B.P.).

[17] Given the above considerations, using the maximal $20 \%$ error on the classical Vostok $\Delta$ age (GT4 [Petit et al., $1999]$ ) and a $10 \%$ uncertainty for the NorthGRIP $\Delta$ age, the total relative error bar on the common Vostok $\delta D_{\text {ice }}$ and NorthGRIP $\delta^{18} \mathrm{O}_{\text {ice }}$ timescale is variable in time within \pm 1550 years over the sequence of DO 23 and 25 .

[18] Within these error bars, we can state without ambiguity that the transition between the stages $5 \mathrm{~d}$ and $5 \mathrm{c}$ in Vostok temperature precedes NorthGRIP DO 24 rapid temperature increase by $1700 \pm 1000$ years (Figure 1). It should be noted that this Antarctic lead was suggested by Caillon et al. [2003a] based on a $\mathrm{CH}_{4} / \delta^{15} \mathrm{~N}$ comparison on Vostok samples. Here we confirm and quantify the lead of the Southern Hemisphere $5 \mathrm{~d} / 5 \mathrm{c}$ transition with respect to the Northern Hemisphere rapid temperature increase of DO 24. Finally, this result shows a good agreement with thermodynamic model predictions describing the northsouth seesaw behavior [Stocker and Johnsen, 2003; Knutti et al., 2004]: such a model predicts that the increase of Antarctic temperature occurs at the beginning of the DO cold phase as depicted in Figure 1.

\subsection{MD95-2042 on NorthGRIP Timescale}

[19] We follow the method depicted by Shackleton et al. [2000] over MIS 3 to construct a chronology for marine core MD95-2042 over the glacial inception which is consistent with NorthGRIP ice core timescale (and therefore Vostok GT4 timescale). The correlation performed by Shackleton et al. [2000] was based on the identification of each midslope point of the DO onsets recorded in the marine and ice core records, which is sometimes difficult during MIS 3 (e.g., the identifications of DO 15 to 18 , between 64 and 52 kyr B.P.). During the glacial inception, the identification of the first DO events $(23,24$ and even the smaller 25) is unambiguous [North Greenland Ice Core members, 2004].

[20] Assuming that the rapid temperature increases and decreases are synchronous between the Iberian Margin and Greenland, six tie points (five midpoints of DO recorded in $\delta^{18} \mathrm{O}_{\text {planktonic }}$ and $\delta^{18} \mathrm{O}_{\text {ice }}$ and one point on the 5e plateau) are used to produce a new timescale for the core MD95- 


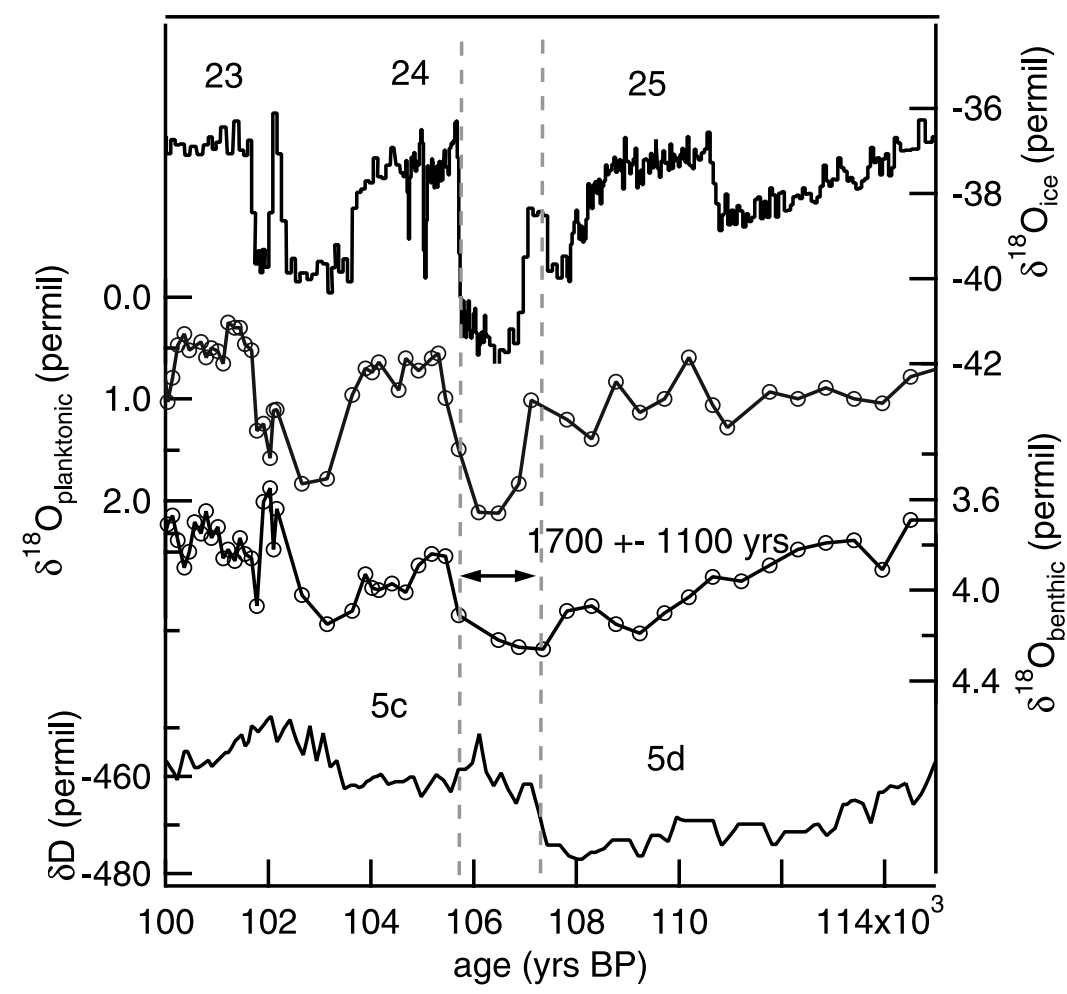

Figure 2. Focus on Dansgaard-Oeschger (DO) 23, 24, and 25 on the GT4 timescale. (top to bottom) NorthGRIP $\delta^{18} \mathrm{O}_{\text {ic }}$, MD95-2042 $\delta^{18} \mathrm{O}_{\text {planktonic }}$, MD 95-2042 $\delta^{18} \mathrm{O}_{\text {benthic }}$, and Vostok $\delta \mathrm{D}_{\text {ice. }}$. The dashed vertical lines highlight the synchronous decrease of $\delta^{18} \mathrm{O}_{\text {planktonic }}$ and $\delta^{18} \mathrm{O}_{\text {benthic }}$ for the rapid onset of DO 24 as well as the clear lead of Vostok $\delta D_{\text {ice }}$ increase with respect to NorthGRIP $\delta^{18} \mathrm{O}_{\text {icee }}$.

2042 over the glacial inception, based on our "GT4" NorthGRIP timescale (Figure 1). Placing the tie points at midslopes during both the temperature increases and decreases is a significant improvement compared to the correlation by Shackleton et al. [2000] since the accumulation rate, and therefore the depth/age relationships do significantly change between stadials and interstadials in central Greenland [Johnsen et al., 1997].

[21] The uncertainty on the relative dating of core MD952042 with respect to NorthGRIP is twofold: first, the error in defining the midpoints of rapid temperature increases and decreases in both MD95-2042 $\delta{ }^{18} \mathrm{O}_{\text {planktonic }}$ and NorthGRIP ice isotopic records due to the temporal resolution of the records and, second, the uncertainty on the timing of the transitions in core MD95-2042 resulting from the use of $\delta^{18} \mathrm{O}_{\text {planktonic }}$ as a SST proxy. The first uncertainty is \pm 200 years in this portion of the $\delta^{18} \mathrm{O}_{\text {planktonic }}$ record (the uncertainty associated with the temporal resolution of NorthGRIP ice record is 50 years, which is thus negligible here). On the basis of the comparison of midpoints in SST signals obtained by two different methods (foraminifera transfer functions and alkenones) and in $\delta^{18} \mathrm{O}_{\text {planktonic }}$ in neighboring core SU81-18 over the last deglaciation [Duplessy et al., 1981; Bard et al., 2000; Waelbroeck et al., 2001], we estimate that the second uncertainty is about \pm 400 years. Combining these two independent uncertainty estimates, we obtain a resulting uncertainty on the relative dating of core MD95-2042 with respect to NorthGRIP of \pm 450 years.
Taking into account the Vostok/NorthGRIP correlation uncertainty, the dating of core MD95-2042 with respect to Vostok GT4 varies thus between 1100 and 1600 years over DO 23 to 25 (Figure 1). The comparison between the initial MD95-2042 and our proposed timescale (Figure 1) shows that the maximum difference between both timescales is less than 2000 years, largely within the uncertainties of the original MD95-2042 timescale [Shackleton et al., 2003] and of the Vostok GT4 timescale [Petit et al., 1999] (to which the different uncertainties on the MD95-2042/ NorthGRIP and NorthGRIP/Vostok correlations should be added).

\section{Results}

[22] From the Vostok/NorthGRIP gas correlation and MD95-2042 $\delta^{18} \mathrm{O}_{\text {planktonic }}$ NorthGRIP $\delta^{18} \mathrm{O}_{\text {ice }}$ correlation, it is now possible to compare, on the same Vostok GT4 timescale, the MD95-2042 $\delta^{18} \mathrm{O}_{\text {benthic }}$ and the Vostok $\delta \mathrm{D}_{\text {ice }}$. Over the period $123 \mathrm{kyr}$ to $112 \mathrm{kyr}$ B.P. (covering the transition between stage $5 \mathrm{e}$ and stage $5 \mathrm{~d}$ ), the slow increase in $\delta^{18} \mathrm{O}_{\text {benthic }}$ is synchronous or slightly delayed with respect to the Vostok $\delta D_{\text {ice }}$ decrease. However, during the transition from stage $5 \mathrm{~d}$ to stage $5 \mathrm{c}$, the Antarctic $\delta \mathrm{D}$ increase precedes the $\delta^{18} \mathrm{O}_{\text {benthic }}$ decrease. During DO 24, MD95$2042 \delta^{18} \mathrm{O}_{\text {benthic }}$ and $\delta^{18} \mathrm{O}_{\text {planktonic }}$ increases occur in phase. Therefore the 1700 years phase lag discussed in detail between NorthGRIP $\delta^{18} \mathrm{O}_{\text {ice }}$ and Vostok $\delta \mathrm{D}_{\text {ice }}$ at the begin- 
ning of DO 24 directly applies for the phase lag between Antarctic temperature and $\delta^{18} \mathrm{O}_{\text {benthic. }}$. Combining the Vostok/NorthGRIP correlation uncertainty (1000 years) with the one associated with the NorthGRIP/MD95-2042 correlation (450 years), we conclude that Vostok $\delta D_{\text {ice }}$ precedes MD95-2042 $\delta^{18} \mathrm{O}_{\text {benthic }}$ by $1700 \pm 1100$ years for DO 24 (Figure 2). During DO 23, MD95-2042 $\delta^{18} \mathrm{O}_{\text {benthic }}$ slightly leads $\delta^{18} \mathrm{O}_{\text {planktonic }}$ but Vostok $\delta \mathrm{D}_{\text {ice }}$ appears to precede again MD95-2042 $\delta^{18} \mathrm{O}_{\text {benthic }}$ although the dating uncertainty is too high to reach firm conclusions (Antarctic lead of $1100 \pm 1600$ years, Figure 2).

[23] Our most important conclusion is that Vostok $\delta D_{\text {ice }}$ and MD95-2042 $\delta^{18} \mathrm{O}_{\text {benthic }}$ were not in phase during the first large rapid climatic change of the glacial inception (DO 24) which is in contradiction with the conclusion of Shackleton et al. [2000] over MIS 3. Because (1) variations in deepwater temperature were shown to induce large phase shifts between Antarctic ice isotopes and Iberian margin cores $\delta^{18} \mathrm{O}_{\text {benthic }}$ over the last deglaciation [Skinner et al., 2003] and (2) local deepwater temperature most likely significantly varied during the last glacial period, core MD95-2042 being close to regions of deepwater formation [Waelbroeck et al., 2002], we suggest that Antarctic ice isotopic signal and MD95-2042 $\delta^{18} \mathrm{O}_{\text {benthic }}$ were probably not in phase during MIS 3 either. The exact phase shift between Vostok $\delta \mathrm{D}_{\text {ice }}$ and MD95-2042 $\delta^{18} \mathrm{O}_{\text {benthic }}$ during MIS 3 can, however, not be precisely evaluated (not discussed by Shackleton et al. [2000]) and the uncertainties on the dating are larger during that period than in the present study because of the aforementioned problem of ambiguous DO identification. Finally, the fact that core MD95-2042 $\delta^{18} \mathrm{O}_{\text {benthic }}$ and $\delta^{18} \mathrm{O}_{\text {planktonic }}$ signals are in phase over DO 24 , whereas Antarctic $\delta D_{\text {ice }}$ exhibits a clear lead with respect to Greenland $\delta^{18} \mathrm{O}_{\text {ice }}$, points to different controlling factors for MD95-2042 $\delta^{18} \mathrm{O}_{\text {benthic }}$ and Antarctic $\delta \mathrm{D}_{\text {ice }}$ signals. The data presented here clearly indicate that factors other than rapid sea level changes have to be invoked to explain the relation between MD95-2042 $\delta^{18} \mathrm{O}_{\text {benthic }}$ and Antarctic $\delta D_{\text {ice }}$ signals.

\section{Conclusion}

[24] We combined detailed ice and gas measurements in the NorthGRIP and Vostok ice cores with the high-resolution marine records $\left(\delta^{18} \mathrm{O}_{\text {planktonic }}\right.$ and $\left.\delta^{18} \mathrm{O}_{\text {benthic }}\right)$ from marine core MD95-2042 to perform a cautious comparison of Antarctic $\delta \mathrm{D}_{\text {ice }}$ and $\delta^{18} \mathrm{O}_{\text {benthic }}$ over the glacial inception. After a careful evaluation of all relative dating uncertainties, we demonstrate that $\delta^{18} \mathrm{O}_{\text {benthic }}$ and $\delta \mathrm{D}_{\text {ice }}$ increases were not synchronous at the onset of DO 24: The Antarctic $\delta D_{\text {ice }}$ increase precedes by at least $1700 \pm 1100$ years the onset of DO 24 in NorthGRIP $\delta^{18} \mathrm{O}_{\text {ice }}$, MD95-2042 $\delta^{18} \mathrm{O}_{\text {planktonic }}$ and $\delta^{18} \mathrm{O}_{\text {benthic }}$ records. While the asynchrony between southern and northern temperatures is a pattern characterizing the whole glacial period, it is clearly not the case for the $\delta^{18} \mathrm{O}_{\text {planktonic }} / \delta^{18} \mathrm{O}_{\text {benthic }}$ relationship since both are in phase over this DO. This result therefore implies that, contrary to the conclusion of Shackleton et al. [2000], North Atlantic $\delta^{18} \mathrm{O}_{\text {benthic }}$ records cannot be assumed to be synchronous with Antarctic temperatures over the entire last glacial period. Antarctic $\delta \mathrm{D}_{\text {ice }}$ possibly also leads North Atlantic $\delta^{18} \mathrm{O}_{\text {benthic }}$ during MIS 3, although the dating uncertainty is too high to establish clear phase lag estimates for that period of time. Other methods to synchronize ice cores and marine records within a few centuries must thus be developed.

[25] Acknowledgments. We thank Jean Jouzel, Sigfus Johnsen, and Dorthe Dahl-Jensen for discussion. We thank the NorthGRIP participants for their cooperative efforts. This work was supported by the Pole-OceanPole (EVK-2000-00089) project funded by the European Union, the French CNRS, CEA, and the Balzan Foundation. A.L. is funded by a Lady Davis Fellowship.

\section{References}

Alley, R. B., et al. (2003), Abrupt climate change, Science, 1999, 2005-2010.

Arnaud, L., J.-M. Barnola, and P. Duval (2000), Physical modeling of the densification of snow/firn and ice in the upper part of polar ice sheets, in Physics of Ice Core Records, edited by T. Hondoh, pp. 285-305, Hokkaido Univ. Press, Sapporo, Japan.

Bard, E., F. Rostek, J.-L. Turon, and S. Gendreau (2000), Hydrological impact of Heinrich events in the subtropical northeast Atlantic, Science, 289, 1321-1324.

Barnola, J. M., P. Pimienta, D. Raynaud, and Y. S. Korotkevich (1991), $\mathrm{CO}_{2}$ climate relationship as deduced from the Vostok ice core: A re-examination based on new measurements and on a re-evaluation of the air dating, Tellus, Ser $B, 43(2), 83-91$.

Bender, M., et al. (1994), Climate correlations between Greenland and Antarctica during the last 100,000 years, Nature, 372, 663-666.

Bender, M., B. Malaizé, J. Orchado, T. Sowers, and J. Jouzel (1999), High precision correlations of Greenland and Antarctic ice core records over the last $100 \mathrm{kyr}$, in Mechanisms of Global Climate Change at Millennial Time Scales, Geophys. Monogr. Ser., vol.
112, edited by P. U. Clark, R. S. Webb, and L. D. Keigwin pp. 149-164, Washington, D. C.

Blunier, T., and E. J. Brook (2001), Timing of millennial-scale climate change in Antarctica and Greenland during the last glacial period, Science, 291, 109-112.

Blunier, T., et al. (1998), Asynchrony of Antarctic and Greenland climate change during the last glacial period, Nature, 394, 739-743.

Bond, G., et al. (1993), Correlations between climate records from North Atlantic sediments and Greenland ice, Nature, 365, 143-147.

Bond, G., et al. (1997), A pervasive millennialscale cycle in North Atlantic Holocene and glacial climate, Science, 278, 1257-1266.

Broecker, W. S., D. M. Peteet, and D. Rind (1985), Does the ocean-atmosphere system have more than one stable mode of operation?, Nature, 315, 21-25.

Broecker, W. S. (1994), Massive iceberg discharges as triggers for global climate change, Nature, 372, 421-424.

Caillon, N., et al. (2001), Estimation of temperature change and gas age-ice age difference, 108 kyr B.P., at Vostok, Antarctica, J. Geophys. Res., 106(D23), 31,893-31,901.
Caillon, N., J. Jouzel, J. P. Severinghaus, J. Chappellaz, and T. Blunier (2003a), A novel method to study the phase relationship between Antarctic and Greenland climates, Geophys. Res. Lett., 30(17), 1899, doi:10.1029 2003GL017838.

Caillon, N., et al. (2003b), Timing of atmospheric $\mathrm{CO}_{2}$ and Antarctic temperature changes across Termination III, Science, 299, $1728-1731$.

Chappell, J. (2002), Sea level changes forced ice breakouts in the last glacial cycle: New results from coral terraces, Quat. Sci. Rev., 21, 12291240

Chappell, J., and N. Shackleton (1986), Oxygen isotopes and sea level, Nature, 324, 137-140.

Chappellaz, J., et al. (1993), Synchronous changes in atmospheric $\mathrm{CH} 4$ and Greenland climate between 40 and $8 \mathrm{kyr} \mathrm{BP}$, Nature, 366, 443-445.

Cortijo, E., P. Yiou, L. Labeyrie, and M. Cremer (1995), Sedimentary record of rapid climatic variability in the North Atlantic Ocean during the last glacial cycle, Paleoceanography, 10(5), 911-926.

Dansgaard, W., et al. (1984), North Atlantic climatic oscillations revealed by deep Greenland 
ice cores, in Climate Processes and Climate Sensitivity, vol. 29, edited by J. E. Hansen and T. Takahashi, pp. 288-298, AGU, Washington, D. C.

Dansgaard, W., et al. (1993), Evidence for general instability of past climate from a $250-\mathrm{kyr}$ ice-core record, Nature, 364, 218-220.

de Abreu, L., N. J. Shackleton, J. Schonfeld, M. Hall, and M. Chapman (2003), Millennialscale oceanic climate variability off the western Iberian margin during the last two glacial periods, Mar. Geol., 196(1-2), 1-20.

Delmotte, M., et al. (2004), Atmospheric methane during the last four glacial-interglacial cycles: Rapid changes and their link with Antarctic temperature, J. Geophys. Res., 109(D11), D 12104 , doi:10.1029/ 2003 JD004417.

Duplessy, J. C., G. Delibrias, J. L. Turon, C. Pujol, and J. Duprat (1981), Deglacial warming of the northeastern Atlantic Ocean: Correlation with paleoclimatic evolution of the European continent, Palaeogeogr. Palaeoclimatol. Palaeoecol., 35, 121-144.

Elliot, M., L. Labeyrie, and J.-C. Duplessy (2002), Changes in North Atlantic deep-water formation associated with the DansgaardOeschger temperature oscillations $(60-10$ ka), Quat. Sci. Rev., 21, 1153-1165.

Flückiger, J., et al. (2004), $\mathrm{N}_{2} \mathrm{O}$ and $\mathrm{CH}_{4}$ variations during the last glacial epoch: Insight into global processes, Global Biogeochem. Cycles, 18, GB1020, doi:10.1029/2003GB002122.

Goujon, C., J.-M. Barnola, and C. Ritz (2003), Modeling the densification of polar firn including heat diffusion: Application to close-off characteristics and gas isotopic fractionation for Antarctica and Greenland sites, J. Geophys. Res., 108(D24), 4792, doi:10.1029/ 2002JD003319.

Grootes, P. M., M. Stuiver, J. W. C. White, S. J. Johnsen, and J. Jouzel (1993), Comparison of the oxygen isotope records from the GISP2 and GRIP Greenland ice cores, Nature, 366, 552-554.

Johnsen, S. J., et al. (1997), The $\delta^{18} \mathrm{O}$ record along the Greenland Ice Core Project deep ice core and the problem of possible Eemian climatic instability, J. Geophys. Res., 102(C12), 26,397-26,410.

Jouzel, J., et al. (2003), Magnitude of isotope/ temperature scaling for interpretation of central Antarctic ice cores, J. Geophys. Res., 108(D12), 4361, doi:10.1029/2002JD002677.

Knutti, R., J. Flueckiger, T. F. Stocker, and A. Timmermann (2004), Strong hemispheric coupling of glacial climate through freshwater discharge and ocean circulation, Nature, 430, $851-856$.

Labeyrie, L. D., and J. C. Duplessy (1985), Changes in the oceanic ${ }^{13} \mathrm{C} /{ }^{12} \mathrm{C}$ ratio during the last 140,000 years: High-latitude surface water records, Palaeogeogr. Palaeoclimatol. Palaeoecol., 50, 217-240.

Labeyrie, L., J. Jouzel, C. Levi, and E. Cortijo (2004), Changements abrupts dans un monde glaciaire, C.R. Geosci., 336(7-8), 721-732.

Labeyrie, L., C. Waelbroeck, E. Cortijo, E. Michel, and J. C. Duplessy (2005), Changes in deep water hydrology during the last glaciation, C.R. Geosci., 337(10-11), 919-927.

Landais, A., et al. (2003), A tentative reconstruction of the last interglacial and glacial inception in Greenland based on new gas measurements in the Greenland Ice Core Pro- ject (GRIP) ice core, J. Geophys. Res., 108(D18), 4563, doi:10.1029/2002JD003147.

Landais, A., et al. (2004a), A continuous record of temperature evolution over a whole sequence of Dansgaard-Oeschger during marine isotopic stage 4 (76 to $62 \mathrm{kyr} \mathrm{BP}$ ), Geophys. Res.Lett., 31, L22211, doi:10.1029/ 2004GL021193.

Landais, A., et al. (2004b), A method for precise quantification of temperature change and phasing between temperature and methane increases through gas measurements on Dansgaard-Oeschger event 12 (-45 kyr), Earth Planet. Sci. Lett., 225, 221-232.

Landais, A., et al. (2005a), The glacial inception recorded in the NorthGRIP Greenland ice core: Information from air isotopic measurements, Clim. Dyn, doi:10.1007/ss00382-005-0063-y, in press.

Landais, A., et al. (2005b), Firn-air $\delta^{15} \mathrm{~N}$ in modern polar sites and glacial-interglacial ice: A model-data mismatch during glacial periods in Antarctica?, Quat. Sci. Lett., in press.

Lang, C., M. Leuenberger, J. Schwander, and S. Johnsen (1999), $16^{\circ} \mathrm{C}$ rapid temperature variation in central Greenland 70,000 years ago, Science, 286, 934-937.

Martrat, B., et al. (2004), Abrupt temperature changes in the western Mediterranean over the past 250,000 years, Science, 306, $1762-$ 1765.

McManus, J. F., et al. (1994), High-resolution climatic records from the N. Atlantic during the last interglacial, Nature, 371, 326-329.

McManus, J. F., R. Francois, J. M. Gherardi, L. D. Keigwin, and S. Brownleger (2004), Collapse and rapid resumption of Atlantic meridional circulation linked to deglacial climate changes, Nature, 428, 834-837.

North Greenland Ice Core members (2004), High-resolution climate record of Northern Hemisphere climate extending into the last interglacial period, Nature, 431, 147-151.

Parrenin, F., F. Remy, C. Ritz, M. J. Siegert, and J. Jouzel (2004), New modeling of the Vostok ice flow line and implication for the glaciological chronology of the Vostok ice core, J. Geophys. Res., 109, D20102, doi:10.1029/ 2004JD004561.

Petit, J. R., et al. (1999), Climate and atmospheric history of the past 420,000 years from the Vostok ice core, Antarctica, Nature, 399, 429-436.

Potter, E. K., et al. (2004), Suborbital-period sealevel oscillations during marine isotope substages 5a and 5c, Earth Planet. Sci. Lett., 225, $191-204$

Rohling, E. J., and G. R. Bigg (1998), Paleosalinity and $\delta^{18} \mathrm{O}$ : A critical assessment, J. Geophys. Res., 103(C1), 1307-1318.

Schwander, J., et al. (1997), Age scale of the air in the summit ice: Implication for glacial-interglacial temperature change, J. Geophys. Res., 102(D16), 19,483-19,493.

Severinghaus, J. P., and J. Brook (1999), Abrupt climate change at the end of the last glacial period inferred from trapped air in polar ice, Science, 286, 930-934

Severinghaus, J., T. Sowers, E. Brook, R. Alley, and M. Bender (1998), Timing of abrupt climate change at the end of the Younger Dryas interval from thermally fractionated gases in polar ice, Nature, 391, 141-146.

Severinghaus, J., M. Fahnestock, M. Albert, T. Scambos, and C. Shuman (2004), Do deep convective zones exist in low-accumulation firn?, Eos Trans. $A G U, 85(47)$, Fall Meet. Suppl., Abstract C31C-07.

Shackleton, N. J. (2000), The 100,000-year iceage cycle identified and found to lag temperature, carbon dioxide, and orbital eccentricity, Science, 289, 1897-1902.

Shackleton, N. J., M. A. Hall, and E. Vincent (2000), Phase relationships between millennial-scale events $64,000-24,000$ years ago, Paleoceanography, 15, 565-569.

Shackleton, N. J., M. Chapman, M. F. SanchezGoñi, D. Pailler, and Y. Lancelot (2002), The classic marine isotope substage 5e, Quat. Res., $58,14-16$

Shackleton, N. J., M. F. Sanchez-Goñi, D. Pailler, and Y. Lancelot (2003), Marine isotope substage $5 \mathrm{e}$ and the Eemian interglacial, Global Planet. Change, 36, 151-155.

Siddall, M., et al. (2003), Sea-level fluctuations during the last glacial cycle, Nature, 423 , $853-858$.

Siddall, M., et al. (2004), Understanding the Red Sea response to sea level, Earth Planet. Sci. Lett., 225, 421-434.

Skinner, L. C., and N. J. Shackleton (2005), An Atlantic lead over Pacific deep-water change across Termination I: Implications for the application of the marine isotope stage stratigraphy, Quat. Sci. Rev., 24, $571-581$.

Skinner, L. S., N. J. Shackleton, and H. Elderfield (2003), Millennial-scale variability of deepwater temperature and $\delta^{18} \mathrm{O}_{\mathrm{dw}}$ indicating deep-water source variations in the northeast Atlantic, 0-34 cal. ka BP, Geochem. Geophys. Geosyst., 4(12), 1098, doi:10.1029/ 2003 GC000585.

Sowers, T. A., M. Bender, D. Raynaud, and Y. S. Korotkevich (1992), $\delta^{15} \mathrm{~N}$ of $\mathrm{N}_{2}$ in air trapped in polar ice: A tracer of gas transport in the firn and a possible constraint on ice age-gas age differences, J. Geophys. Res., 97(15), 15,683-15,697.

Stocker, T. F. (1998), The seesaw effect, Science, 282, 61-62.

Stocker, T. F., and S. J. Johnsen (2003), A minimum thermodynamic model for the bipolar seesaw, Paleoceanography, 18(4), 1087, doi:10.1029/2003PA000920.

Waelbroeck, C., et al. (2001), The timing of the last deglaciation in North Atlantic climate records, Nature, 412, 724-727.

Waelbroeck, C., et al. (2002), Sea level and deep temperature changes derived from benthic foraminifera benthic records, Quat. Sci. Rev., 21, 295-306.

Yokoyama, Y., T. M. Esat, and K. Lambeck (2001), Coupled climate and sea-level changes deduced from Huon Peninsula coral terraces of the last ice age, Earth Planet. Sci. Lett., 193, $579-587$.

A. Landais, Institute of Earth Sciences, Givat Ram, Hebrew University, 91904 Jerusalem, Israel. (landais@vms.huji.ac.il)

V. Masson-Delmotte and C. Waelbroeck, Laboratoire des Sciences du Climat et de l'Environnement, Institut Pierre-Simon Laplace, Orme des merisiers, 91191 Gif sur Yvette, France. 